\title{
Caries Incidence and Costs of Prevention Programs
}

\author{
A. Isabel Garcla, DDS, MPH \\ Program in Dental Public Health \\ School of Public Health \\ The University of Michigan \\ Ann Arbor, MI 48109-2029
}

\begin{abstract}
Data on caries increments and costs of prevention programs are presented as background information for participants in the workshop. Estimates of annual caries increments were derived from control groups in clinical trials, epidemiologic studies, and national surveys. Cost data were obtained from dental public health directors, program administrators, fluoridation engineers, and water plant operators in different parts of the US. Caries incidence data are reported for age groups: $5-17$ years (fluoridated and nonfluoridated areas), 18-44 years, 4564 years, and 65 and over. Program costs include direct costs primarily and do not allow for program inefficiencies, nor have they attempted to include social costs. All cost data are expressed in 1988 dollars. Direct program costs are included for community water fluoridation, fluoride supplements, fluoride mouthrinses, school fluoridation, and sealant programs. For professionally and self-applied fluoride programs, only material and salary costs are included because total costs could not be located in the literature nor obtained from program directors. All factors and necessary assumptions included in the cost assessments are described.
\end{abstract}

Key Words: caries incidence, costs of prevention, dental public heaith.

This report presents the data collected for use by the work groups as part of their source material. The data are presented in two sections: the first summarizes pertinent information on caries experience in children, adults, and the elderly in the US and Canada over the last ten years; the second includes reported costs of six types of caries prevention programs currently in effect throughout the United States. This paper is not intended to be a comprehensive review of the literature, nor an exhaustive account of caries prevention programs in the United States. Rather, it is intended to be a reasonably representative selection of recent data from a number of sources, sufficient to provide sound basic information on which the work groups can base their calculations.

\section{A. Caries Incidence}

Included in this section are incidence data from control groups in caries clinical trials and community trials, together with imputed incidence from epidemiologic surveys conducted in the US and Canada since 1978. Caries experience data for children, adults, and the elderly are summarized in Tables 1-7.

Four criteria were used to select the studies for this review: date of the study, type of experimental design, length of the trial, and completeness of the published reports. Because the results of studies performed during the early 1970 s would probably not portray a realistic picture of caries experience today, the first criterion was to limit the studies to those conducted in recent years. Although a number of studies published in the late 1970s met this criterion, they were not included in the review because data had been collected up to ten years earlier, making them too old for use in the workshop. Deriving incidence data from clinical trials required that caries increments be reported for study participants not receiving the preventive regimens being tested, that is, control groups. Thus, the second criterion tended to exclude demonstration projects and studies using historical comparisons or cross-sectional controls.

The third criterion was needed in view of the recognized caries decline in recent years. As the period of time required for caries development increases, longer clinical trials are needed. Hence, studies of a minimum duration of two years were selected. It should be noted that two exceptions to this rule were made in the 45-64 and 65+ age categories (Kohout F, College of Dentistry and the Center for Health Services Research, University of lowa; Papas A, Joshi A, Tufts University School of Dental Medicine, Boston. All personal communications, Feb 1989). Both studies, conducted for less than two years, were included in Tables 6-7 because of the sparse information for these age groups.

Finally, details regarding the conduct of the trial, such as the selection of subjects, study protocol, diagnostic criteria, and analysis of data were used to judge the quality of the various studies. Studies published only as abstracts have therefore been omitted from this report.

Children: Aged 5-17. Estimates of annual caries increments for children aged 5-17 were derived from the control groups of studies summarized in Tables 1-4. While control group participants would not have been affected by the preventive intervention understudy, they 
A. CARIES INCIDENCE: TABLE 1

Caries Experience of Children Aged 5-15 from fluoride-deficient Communities in the US and Canada: Annual DMFS Increments of Controls from Caries Clinical Trials, 1978-88*

\begin{tabular}{|c|c|c|c|c|c|c|}
\hline Authors and Year & Type of Trial & $\begin{array}{c}\text { Age at } \\
\text { Baseline }\end{array}$ & $\mathbf{N}$ & Location & $\begin{array}{l}\text { Length of } \\
\text { Study (Years) }\end{array}$ & $\begin{array}{c}\text { Annual DMFS } \\
\text { Increment }\end{array}$ \\
\hline $\begin{array}{l}\text { NPDDP }^{1} 1977-78 \text { to } \\
1981-82\end{array}$ & Combined treatment & $6-7$ & 740 & MA, FL, KSt,LA,WA & 4.0 & 0.8 \\
\hline $\begin{array}{l}\text { NPDDP }^{1} 1977-78 \text { to } \\
1981-82\end{array}$ & Combined treatment & appr. 10 & 296 & MA, FL, KSt, LA, WA & 4.0 & 1.2 \\
\hline Ripa et al. ${ }^{2} 1979-82$ & APF gel & $10-13$ & 324 & Long Island, NY & 3.0 & $1.1^{* *}$ \\
\hline $\begin{array}{l}\text { Abrams and Chambers }{ }^{3} \\
(1980)\end{array}$ & Dentifrice & $5-12$ & 380 & San Francisco, CA & 3.0 & 2.6 \\
\hline Triol et al. ${ }^{4}(1980)$ & $\begin{array}{l}\text { Dentifrice \& } \\
\text { mouthrinse }\end{array}$ & $10-13$ & 266 & Brookline, MA & 2.5 & $1.2 \ddagger$ \\
\hline Glass $^{5}(1981)$ & Dentifrice & $6-11$ & 211 & MA & 2.5 & $2.0^{* * *}$ \\
\hline Clark et al. ${ }^{6} 1981-86$ & Fluoride varnish & $6-7$ & 189 & Quebec, Canada & 4.7 & 0.9 \\
\hline Ringelberg et al. ${ }^{7}$ (1982) & Fluoride mouthrinse & 12.5 & 249 & Polk County, FL & 2.0 & 1.7 \\
\hline \multirow[t]{2}{*}{ Heifetz et al. ${ }^{8}$ (1982) } & Fluoride mouthrinse & $10-12$ & 87 & Biddeford, ME & 3.0 & $1.2 \mathrm{H}$ \\
\hline & & & 117 & & & 1.5 \\
\hline Ripa et al. ${ }^{9} 1982-85$ & Dentifrice & $9-15$ & 827 & Long Island, $\mathrm{NY}$ & 3.2 & $1.2 \ddagger$ \\
\hline Burt et al. ${ }^{10} 1982-85$ & Diet study & $10-15$ & 499 & Coldwater, MI & 3.0 & 1.0 \\
\hline Glass $^{11}(1983)$ & Sorbitol & $7-11$ & 271 & MA & 2.0 & $2.4^{* * *}$ \\
\hline Lu et al. ${ }^{12}(1987)$ & Dentifrice & $7-15$ & 703 & Portland, OR & 3.0 & $1.5 \ddagger$ \\
\hline Conti et al. ${ }^{13}$ (1988) & Dentifrice & $7-14$ & 1,228 & Polk County, FL & 3.0 & $0.8 \ddagger$ \\
\hline All & & & & & & $\begin{array}{c}\text { Mean }=1.4 \\
\text { Median=1.2 } \\
\text { Range }=0.8-2.6\end{array}$ \\
\hline
\end{tabular}

*Trials are listed according to date of study if known; otherwise, publication date (in parentheses) is used.

t0.4 ppm fluoride.

**Positive control (biannual APF gel).

$\ddagger$ Positive control group $(1,000-1,100$ ppm $F /$ dentifrice).

***DFS rate.

$t+$ Reports from two different examiners.

TABLE 2

Caries Experience of Children Aged 6-15 from Fluoride-deficient Communities in the US and Canada: Surface-specific DMFS Increments of Controls from Caries Clinical Trials, 1978-86*

\begin{tabular}{|c|c|c|c|c|c|c|c|}
\hline \multirow[b]{2}{*}{ Authors and Year } & \multirow{2}{*}{$\begin{array}{l}\text { Age at } \\
\text { Baseline }\end{array}$} & \multirow[b]{2}{*}{$\mathbf{N}$} & \multirow{2}{*}{$\begin{array}{c}\text { Length of } \\
\text { Study (Years) }\end{array}$} & \multicolumn{4}{|c|}{ Annual DMFS Increments } \\
\hline & & & & Proximal & Buccolingual & Occlusal & Total \\
\hline $\mathrm{NPDDP}^{1} 1978-82$ & $6-7$ & 740 & 4.0 & 0.10 & 0.25 & 0.43 & 0.78 \\
\hline NPDDP $^{1} 1978-82$ & $\sim 10$ & 296 & 4.0 & 0.27 & 0.26 & 0.65 & 1.18 \\
\hline Ripa et al. ${ }^{2} 1979-82$ & $10-13$ & 324 & 3.0 & 0.20 & 0.29 & 0.62 & 1.11 \\
\hline Clark et al. ${ }^{6} 1981-86$ & $6-7$ & 189 & 4.7 & 0.13 & 0.27 & 0.53 & 0.93 \\
\hline \multirow[t]{2}{*}{ Heifetz et al. ${ }^{8}$ (1982) $†$} & $10-12$ & 87 & 3.0 & 0.46 & 0.24 & 0.50 & 1.20 \\
\hline & & 117 & & 0.57 & 0.34 & 0.57 & 1.48 \\
\hline Ripa et al. ${ }^{9} 1982-85$ & $9-15$ & 827 & 3.2 & 0.23 & 0.28 & 0.65 & 1.16 \\
\hline All & & & & $\begin{array}{c}\text { Mean }=0.3 \\
\text { Median }=0.2 \\
\text { Range }=0.1-0.6\end{array}$ & $\begin{array}{c}0.3 \\
0.3 \\
0.2-0.3\end{array}$ & $\begin{array}{c}0.6 \\
0.6 \\
0.4-0.7\end{array}$ & $\begin{array}{r}1.1 \\
1.2 \\
0.8-1.5\end{array}$ \\
\hline
\end{tabular}

*Trials are listed according to date of study; if unknown, publication date (in parentheses) is used.

tResults of two examiners. 
TABLE 3

Caries Experience of Children Aged 6-13 from Fluoridated Communities in the US: Annual DMFS Increments of Controls from Caries Clinical Trials, 1978-84*

\begin{tabular}{|c|c|c|c|c|c|c|}
\hline Authors and Year & Material & $\begin{array}{c}\text { Age at } \\
\text { Baseline }\end{array}$ & $\mathbf{N}$ & Location & $\begin{array}{c}\text { Duration } \\
\text { (Years) }\end{array}$ & $\begin{array}{l}\text { Annual DMFS } \\
\text { Increment }\end{array}$ \\
\hline Bagramian et al. ${ }^{14} 1973-78$ & Combined treatment & $6-7$ & 199 & Ypsilanti, MI & 5.0 & 0.5 \\
\hline Driscoll et al. ${ }^{15} 1977-80$ & Mouthrinse & $12-13$ & 151 & Des Moines, IA & 2.5 & $0.9+$ \\
\hline $\mathrm{NPDDP}^{1} 1978-82$ & Combined treatment & $6-7$ & 431 & NY, TN, MN, TX, CA* & 4.0 & 0.6 \\
\hline Fogels et al. ${ }^{17} 1981-84$ & Dentifrice & $6-11$ & 950 & Boston, MA & 3.0 & $0.8 \ddagger$ \\
\hline All & & & & & & $\begin{aligned} \text { Mean } & =0.8 \\
\text { Median } & =0.8 \\
\text { Range }=0.5 & =1.1\end{aligned}$ \\
\hline
\end{tabular}

*Trials are listed according to date of study if known; otherwise, publication date (in parentheses) is used.

tAverage of 2 examiners.

**Intermittent fluoridation during the 1970 s.

$\ddagger$ Positive control group (1,000 ppm dentifrice).

TABLE 4

Caries Experience of Children Aged 6-13 from Fluoridated Communities in the US: Surface-specific DMFS Increments of Controls from Caries Clinical Trials, 1973-82

\begin{tabular}{|c|c|c|c|c|c|c|c|}
\hline \multirow[b]{2}{*}{ Authors and Year } & \multirow{2}{*}{$\begin{array}{c}\text { Age at } \\
\text { Baseline }\end{array}$} & \multirow[b]{2}{*}{$\mathbf{N}$} & \multirow{2}{*}{$\begin{array}{c}\text { Length of } \\
\text { Study (Years) }\end{array}$} & \multicolumn{4}{|c|}{ Annual DMFS Increments } \\
\hline & & & & Proximal & Buccolingual & Occlusal & Total \\
\hline Bagramian et al. ${ }^{14} 1973-78$ & $6-7$ & 199 & 5.0 & 0.04 & 0.14 & 0.28 & 0.46 \\
\hline Bagramian et al. $^{14} 1973-78$ & $11-12$ & 130 & 5.0 & 0.30 & 0.14 & 0.46 & 0.90 \\
\hline Driscoll et al. ${ }^{15} 1977-80$ & $12-13$ & 151 & 2.5 & 0.14 & 0.20 & 0.56 & 0.90 \\
\hline $\mathrm{NPDDP}^{1} 1978-82$ & $6-7$ & 431 & 4.0 & 0.04 & 0.18 & 0.33 & 0.55 \\
\hline $\mathrm{NPDDP}^{1} 1978-82$ & $\sim 10$ & 204 & 4.0 & 0.07 & 0.19 & 0.51 & 0.77 \\
\hline All & & & & $\begin{array}{c}\text { Mean }=0.1 \\
\text { Median }=0.1 \\
\text { Range }=0.04-0.3\end{array}$ & $\begin{array}{c}0.2 \\
0.2 \\
0.1-0.2\end{array}$ & $\begin{array}{c}0.4 \\
0.5 \\
0.3-0.6\end{array}$ & $\begin{array}{c}0.7 \\
0.8 \\
0.5-0.9\end{array}$ \\
\hline
\end{tabular}

probably received benefits from uncontrolled home use of fluoridated dentifrices or from other preventive dental care. From the 17 studies listed in Tables 1-4, only three required participants in control groups to use a nonfluoridated dentifrice $(3,5,16)$. Consequently, the caries experience of the remaining control groups (or positive controls) from these trials is likely to reflect the preventive effects of the widespread use of fluorides in the 1980s.

Surface-specific increments were available for a few of the studies, and are recorded in Tables 2 and 4 . Studies have been listed separately for fluoride-deficient (1-13) and fluoridated communities (1,14-17). Areas of less than $0.3 \mathrm{ppm}$ of fluoride in their water supplies were considered "fluoride-deficient" communities; "fluoridated" communities include areas with optimal fluoride levels for their region ranging from 0.8 to $1.1 \mathrm{ppm}$ fluoride.
Annual caries incidence was calculated as mean, median, and range of decayed, missing, and filled surfaces (DMFS) increment/year. Imputed incidence from national surveys suggests these increments are reasonable estimates for children and young adults.

Adults: Aged 18-44, 45-64, and 65+. While the caries experience of children is well documented, very limited information exists in the literature about the caries incidence of adults. Thus, estimates for these age groups were derived not only from the few studies available (18-20,22-23), but also imputed from the 1985-86 National Survey of Employed Adults and Seniors (21).

Caries experience data for adults aged 18-44, 45-64, and $65+$ are presented in Tables 5-7. The information in these tables must be interpreted with caution for several reasons. First, the number of available studies is sufficient 
TABLE 5

Caries Experience of Adults Aged 18-44 in the US, 1969-86: Annual Caries Increments from Longitudinal, Retrospective Studies, Controls from a Clinical Trial, and the 1985-86 NIDR Survey*

\begin{tabular}{|c|c|c|c|c|}
\hline Authors and Year & Age at Baseline & $\mathbf{N}$ & Length of Study (Years) & Annual DMFS Increment \\
\hline $\begin{array}{l}\text { Glass et al. } \\
\text { 1979-80) }\end{array}$ & $<45 t$ & 262 & 10 & $1.06^{* 4}$ \\
\hline \multirow[t]{2}{*}{ Hyman $^{19}(1983)$} & 21.2 & 120 & $<4 \ddagger$ & 1.38 \\
\hline & 30.2 & 102 & $>4 \ddagger$ & 1.59 \\
\hline \multirow[t]{3}{*}{ Ripa \& Leske ${ }^{20} 1983-86$} & $20-24$ & 18 & 3.0 & 0.91 \\
\hline & $25-34$ & 88 & & 0.71 \\
\hline & $35-44$ & 107 & & 0.75 \\
\hline NIDR $^{21} 1985-86$ & $18-44$ & 9,619 & 23.5 & 1.16 \\
\hline All & & & & $\begin{array}{c}\text { Mean=1.1 } \\
\text { Median=1.1 } \\
\text { Range=0.7-1.6 }\end{array}$ \\
\hline
\end{tabular}

* Listed according to the years during which study was conducted, or by publication date (in parentheses).

tAge at end of study.

${ }^{*+}$ Average DFS rate per 100 surfaces at risk; root caries included for one-third of subjects.

$\ddagger$ Retrospective study of existing dental records.

TABLE 6

Caries Experience of Adults Aged 45-64 in the US, 1969-87: Annual DMFS Increments from the 1985-86 NIDR Adult Survey, a Longitudinal Study, and Controls from a Clinical Trial*

\begin{tabular}{|c|c|c|c|c|c|c|}
\hline \multirow[b]{2}{*}{ Authors and Year } & \multirow{2}{*}{$\begin{array}{c}\text { Age at } \\
\text { Baseline }\end{array}$} & \multirow[b]{2}{*}{$\mathbf{N}$} & \multirow{2}{*}{$\begin{array}{c}\text { Length of } \\
\text { Study (Years) }\end{array}$} & \multicolumn{3}{|c|}{ Annual DFS Increments } \\
\hline & & & & Coronal & Root & Total \\
\hline \multirow[t]{2}{*}{ Glass et al. ${ }^{18}(1987)$} & $45-54 \dagger$ & 321 & 10 & & & $1.43^{* *}$ \\
\hline & $\geq 55 t$ & 146 & & & & $1.76^{* *}$ \\
\hline Ripa and Leske ${ }^{20}(1987)$ & $45-65$ & 137 & 3 & 0.91 & 0.3 & $1.21 \ddagger$ \\
\hline $\mathrm{NIDR}^{21} 1985-86$ & $45-64+$ & 5,513 & 15 & 0.69 & 0.66 & $1.35 \ddagger$ \\
\hline \multirow[t]{2}{*}{ Kohout $^{* * *} 1989$} & $<60$ & 36 & 1 & 1.69 & 0.25 & 1.90 \\
\hline & $60-64$ & 110 & & 1.20 & 0.33 & 1.53 \\
\hline All & & & & $\begin{array}{c}\text { Mean=1.1 } \\
\text { Median=1.1 } \\
\text { Range=0.7-1.7 }\end{array}$ & $\begin{array}{c}0.4 \\
0.3 \\
0.3-0.7\end{array}$ & $\begin{array}{l}1.5 \\
1.5 \\
1.2-1.9\end{array}$ \\
\hline
\end{tabular}

* Listed according to the years during which study was conducted, or by publication date (in parentheses).

tAge at end of study.

**Average DFS rate per 100 surfaces at risk, coronal and root caries included.

†DMFS.

*** Personal communication, F. Kohout, 1989.

for obtaining reasonable estimates of caries experience, but not for deriving precise caries increments. Second, with the exception of national survey data (21), these studies were conducted among specific population subgroups (e.g., Navy personnel, VA patients, regional surveys) whose caries experience may not be representative of the overall adult and elderly population. Last, some researchers have cited difficulties in distinguishing coronal from root caries because a number of different criteria may have been used to define root lesions (24). Thus, the possibility that root caries was scored differently by the various examiners cannot be overlooked.

\section{B. Costs of Prevention Programs}

Derivation of Cost Data. This section presents direct costs of six types of caries-prevention programs: water fluoridation, fluoride supplements, fluoride mouthrinse, school fluoridation, sealants, and fluoride gel applications (see Tables 8-17). It should be noted that the cost information provided in this section includes primarily direct program costs. Other expenditures such as the costs of screening, training of personnel, program promotion, and administrative costs were in most instances unavailable. Administrative and promotional costs were reported by a few states; they are summarized as 
TABLE 7

Caries Incidence of Noninstitutionalized and Institutionalized Adults Aged 65 and Older in the US and Canada, 1981-88*

\begin{tabular}{|c|c|c|c|c|c|c|}
\hline \multirow[b]{2}{*}{ Authors and Year } & \multirow{2}{*}{$\begin{array}{c}\text { Age at } \\
\text { Baseline }\end{array}$} & \multirow[b]{2}{*}{$\mathbf{N}$} & \multirow{2}{*}{$\begin{array}{c}\text { Length of } \\
\text { Study (Years) }\end{array}$} & \multicolumn{3}{|c|}{ Annual DFS Increments } \\
\hline & & & & Coronal & Root & Total \\
\hline \multicolumn{7}{|l|}{ Noninstitutionalized } \\
\hline \multirow[t]{3}{*}{ Hand et al. $.^{22} 1981-84$} & $70-74$ & 152 & 3.0 & 0.82 & 0.28 & 1.10 \\
\hline & $75-79$ & 90 & & 0.87 & 0.35 & 1.22 \\
\hline & $80+$ & 96 & & 0.73 & 0.48 & 1.21 \\
\hline $\mathrm{NIDR}^{21} 1985$ & $65-80+$ & 5,649 & 20 & 1.02 & 0.16 & $1.17 t$ \\
\hline \multirow[t]{2}{*}{ Papas and Joshi** 1988} & $68.8 \ddagger$ & 88 & 1.3 & 0.75 & 0.74 & 1.49 \\
\hline & $78.8 \ddagger$ & 31 & & 1.40 & 1.04 & 2.44 \\
\hline \multirow[t]{3}{*}{ Kohout $^{* * *} 1988$} & $65-69$ & 102 & 1 & 1.21 & 0.75 & 1.96 \\
\hline & $70-74$ & 92 & & 1.59 & 0.64 & 2.23 \\
\hline & $75+$ & 94 & & 0.96 & 0.64 & 1.60 \\
\hline \multicolumn{7}{|l|}{ Institutionalized } \\
\hline Banting et al. ${ }^{23}$ (1985) & $68.6 \#$ & 45 & 2.8 & - & 0.2 & \\
\hline \multirow[t]{3}{*}{ All } & & & & Mean $=1.0$ & 0.6 & 1.7 \\
\hline & & & & Median=1.0 & 0.6 & 1.6 \\
\hline & & & & Range $=0.7-1.6$ & $0.2-1.0$ & $1.1-2.4$ \\
\hline
\end{tabular}

"Listed according to the years during which study was conducted, or by publication date (in parentheses).

tDMFS.

** Personal communication with Drs. A. Papas and A. Joshi.

†Mean age.

***Personal communication, Dr. F. Kohout, 1989.

† Subjects aged $36-89$ at baseline.

"other costs" and detailed below each table. All cost data are reported in 1988 dollars.

Operational costs for community water fluoridation systems shown in Tables 8-9 were gathered via mail surveys and personal communication with water plant operators and state fluoridation engineers, who also provided equipment costs from engineer specification reports. New equipment costs were obtained from vendors of fluoridation equipment and from two fluoridation engineers (Magnant ML, Iowa Department of Health, Iowa City; and Reeves TG, Centers for Disease Control, Atlanta. Both personal communications, Jan 1989). Costs of the remaining caries prevention programs reported in Tables 10-16 were obtained from state dental directors, local directors, and coordinators of specific programs across the US.

Some assumptions were required in estimating annual costs for the various programs. For community water fluoridation systems, the equipment was estimated to last 15 years and to have virtually no resale value. Onetime costs such as installation, building improvements, and consulting engineering fees were included with the capital costs and the entire amount amortized over a 15-year period using 2 percent and 4 percent discount rates. This amount is the annualized or annuitized capital cost. The initial capital costs in Table 8 were adjusted for inflation to compensate for changes in the value of the dollar since the year of purchase. The adjustment factor used is the all urban consumer price index (CPI-U), published by the Bureau of Labor Statistics in The Monthly Labor Review. The CPI-U, introduced in 1978, measures the average change in prices paid by urban consumers in the US for a fixed number of goods and services, and represents the buying habits of about 80 percent of the population (25). Initial capital costs in Table 9 were not adjusted for inflation because they were calculated in 1988 dollars. Annualized capital costs were added to operational costs to obtain the total direct cost per year. Annual per capita costs, calculated for 2 and 4 percent discount rates, are the total direct costs divided by the population served.

Unlike community water fluoridation, fluoride supplement programs and fluoride mouthrinse programs do not involve large capital investments. Therefore, annual program costs shown in Tables 10-12 only reflect personnel and material costs. Other costs such as travel, administration, rent, and utilities are included for some of the programs. Further cost details are discussed under each program heading.

Direct costs of school fluoridation programs are summarized in Table 13. The initial capital costs incurred by school fluoridation programs are comparable to those of community fluoridation systems. They include the cost of fluoridators, testing equipment, engineering, and installation. Consequently, similar assumptions were used to derive costs for these two types of programs. Initial 


\section{B. COSTS OF PREVENTION PROGRAMS : TABLE 8}

Direct Cost of Community Water Fluoridation in the US, 1988, Based on the Capital Cost of Existing Equipment (in US\$)

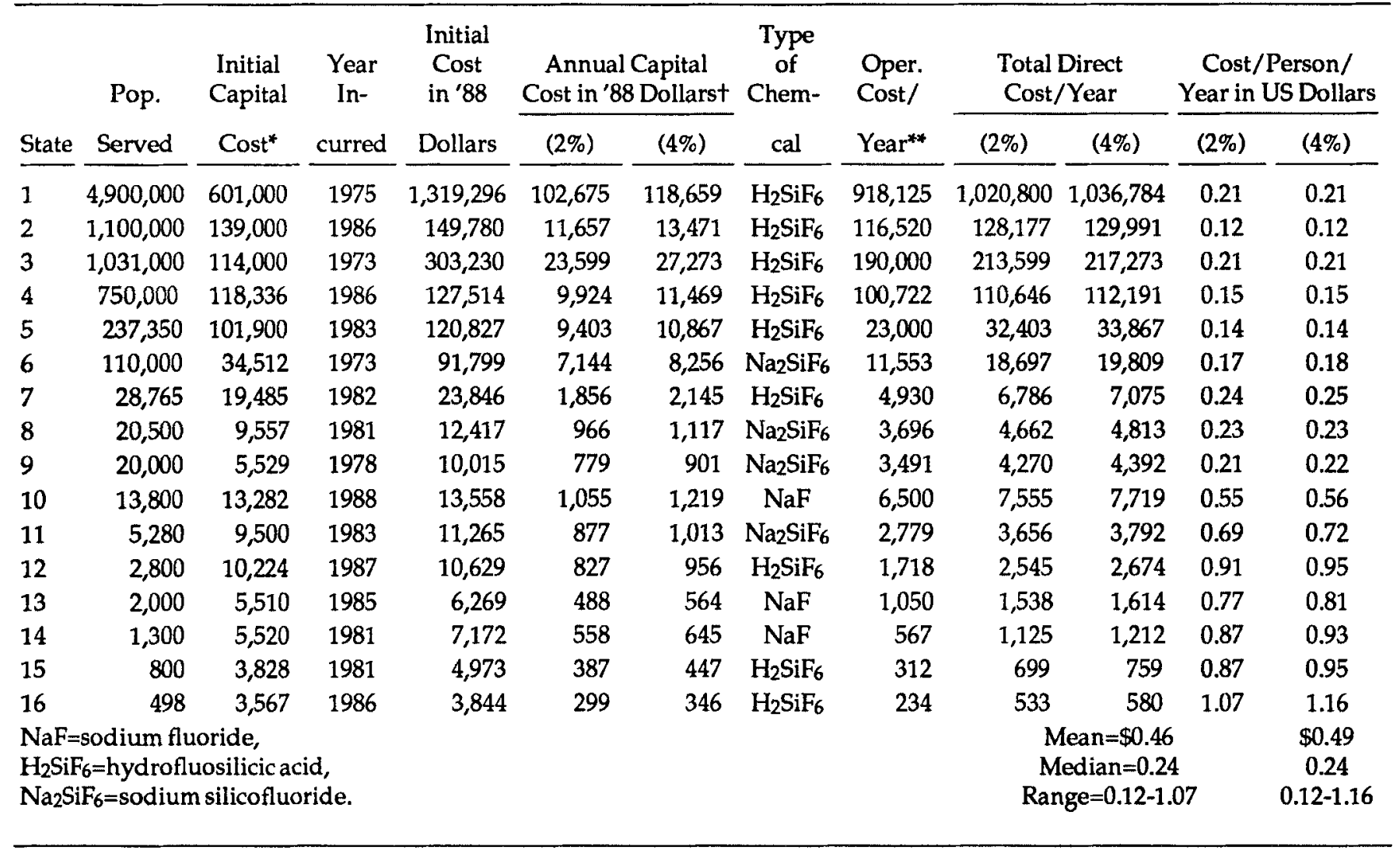

"Equipment and engineering costs. Annualized at $2 \%$ and $4 \%$ over 15 years. ${ }^{*}$ Cost of chemicals, maintenance, and repair.

TABLE 9

Direct Cost of Community Water Fluoridation in the US 1988, based on Equipment Replacement Costs (in US\$)

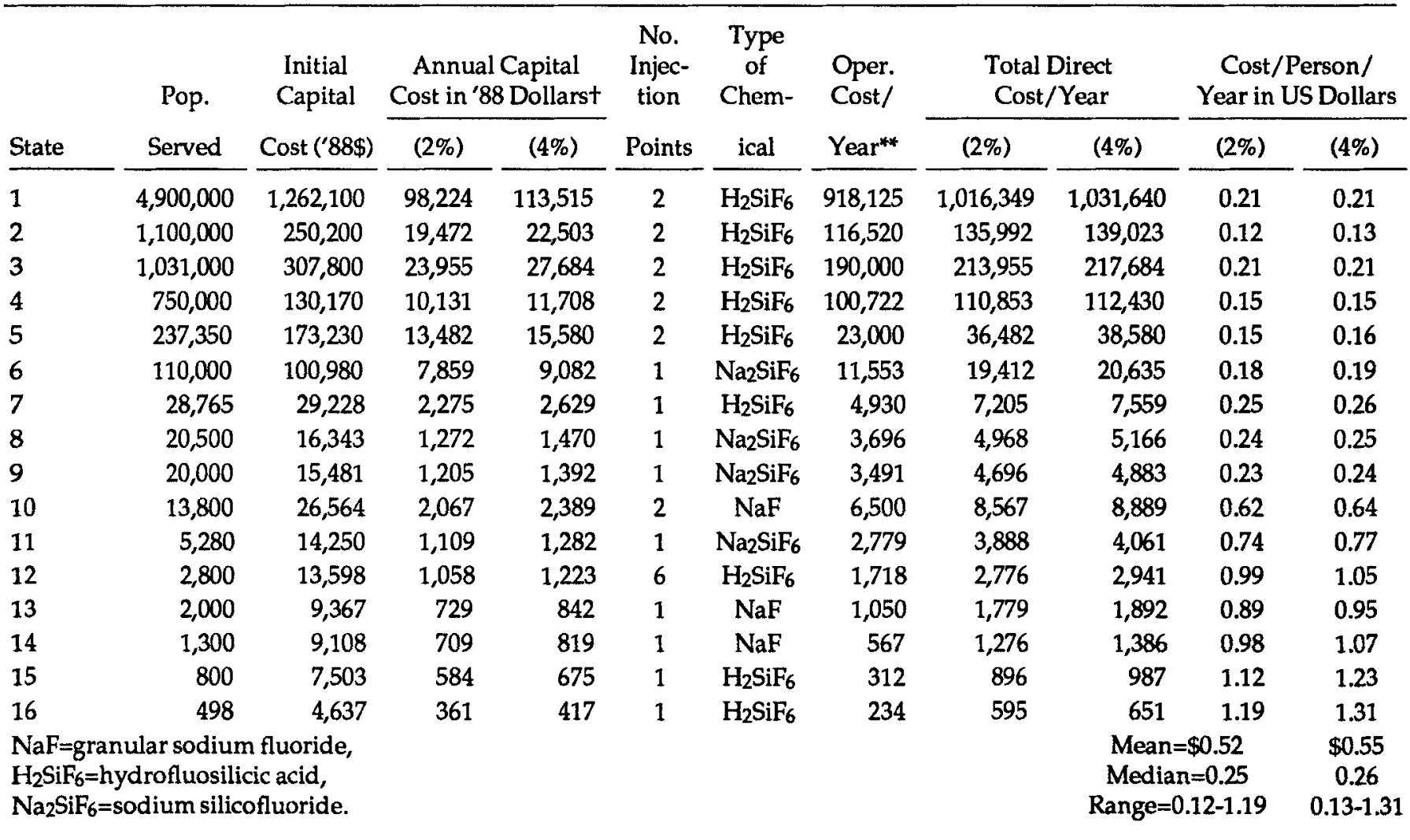

"Estimated equipment replacement cost and installation. $f$ Annualized at $2 \%$ and $4 \%$ over 15 years. "Cost of chemical, maintenance, and repair. 
capital expenditures were estimated using equipment replacement costs in 1988 dollars. Capital costs annualized at 2 percent and 4 percent over a period of 15 years were added to the cost of chemicals, maintenance and repair, testing, personnel, and "other" costs to obtain the annual cost per student. Operational and equipment costs used in Tables 13 and 14 were provided by fluoridation engineers and technicians from each program, and in some instances by state dental directors.

Sealant programs can be conducted in a variety of ways depending on the availability of space, personnel, and characteristics of the particular state program. Therefore, sealants services can be provided as part of an existing clinical program, initiated as a distinct program, or offered through referral programs with services provided by private practitioners. For these reasons, the calculation of annual costs in Tables 15-16 required a different set of assumptions for each type of service delivery. For sealant programs conducted using portable units (set up within schools), initial equipment costs were annualized at 2 percent and 4 percent over a period of ten years. Some programs used dental vans to transport portable equipment to and from schools (unlike dental trailers, which are larger vehicles equipped in most instances for preventive as well as treatment services). Capital costs for the purchase of such vans were also amortized at 2 percent and 4 percent rates of discount, but over a five-year period.

For workshop use, all cost data are presented in ranges. This is done because of the differing approaches to cost derivation used by those providing the information, and because all figures are empirical without allowance for program inefficiencies. These ranges were provided as a basis for the estimation of true costs and for sensitivity analysis by the work groups.

Community Water Fluoridation. Costs of community water fluoridation were obtained from selected communities in the US with systems that have been in operation from one to 14 years. Although these cost figures offer some geographic diversity, the selection of a particular system usually depended on the availability and quality of existing records. A total of 57 water systems throughout the US were surveyed: operators from 42 systems were contacted by telephone, and data for 15 other systems were provided by state dental divisions. Of these 57 cities and communities, 19 returned incomplete reports, six did not respond, and three were no longer fluoridating water supplies. The towns that discontinued fluoridation reported using new wells with natural fluoride levels of $0.3 \mathrm{ppm}$ to $0.5 \mathrm{ppm}$. The most complete and detailed records from 16 water plants were selected from the remaining 29 locations to provide an adequate array of systems for the purposes of the workshop. They are presented in Tables 8-9.

Throughout the process of data collection from the various communities, equipment costs were readily available for recently installed and small fluoridation systems, but such information was often difficult to obtain from larger and older installations. On the other hand, maintenance, repair, and chemical costs were obtained from all communities in detail. For these reasons, the annual costs of fluoridation were also estimated using replacement costs for existing equipment as shown in Table 9. These capital costs include equipment, engineer-

TABLE 10

Direct Annual Costs of Fluoride Supplement Programs in the US (in 1988 US\$)

\begin{tabular}{|c|c|c|c|c|c|c|c|c|c|}
\hline State & No. Schools & $\begin{array}{l}\text { No. } \\
\text { Children }\end{array}$ & Age & $\begin{array}{l}\text { Type \& } \\
\text { Dosage }\end{array}$ & $\begin{array}{c}\text { Personnel } \\
\text { Costs/ } \\
\text { Year }\end{array}$ & $\begin{array}{c}\text { Materials \& } \\
\text { Supplies/ } \\
\text { Year }\end{array}$ & $\begin{array}{l}\text { Other } \\
\text { Costs/ } \\
\text { Year }\end{array}$ & $\begin{array}{l}\text { Total } \\
\text { Costs/ } \\
\text { Year }\end{array}$ & $\begin{array}{c}\text { Costs/ } \\
\text { Child/ } \\
\text { Year }\end{array}$ \\
\hline 1 & 7 & 935 & $6-12$ & $\mathrm{NaF}(1 \mathrm{mg})$ & 458 & 370 & & 828 & 0.89 \\
\hline 2 & $5^{*}$ & 657 & $4-5$ & $\mathrm{NaF}$ (1 mg) & NAt & 756 & & 756 & 1.15 \\
\hline 3 & 49 & 10,751 & $5-14$ & $\mathrm{NaF}(1 \mathrm{mg})$ & 17,264 & 5,805 & $1,200^{\mathrm{a}}$ & 24,269 & 2.26 \\
\hline 4 & 12 & 3,000 & $5-12$ & $\mathrm{NaF}(0.5 \mathrm{mg})$ & 5,278 & 2,000 & $1,500^{b}$ & 8,778 & 2.93 \\
\hline 5 & - & 9,721 & $4-5$ & $\begin{array}{l}\mathrm{NaF}(1 \mathrm{mg}) \\
\text { Tabs or drops }\end{array}$ & 39,290 & 12,000 & $1,200^{c}$ & 52,490 & 5.40 \\
\hline All & & & & & & & & \multicolumn{2}{|c|}{$\begin{array}{c}\text { Mean }=\$ 2.53 \\
\text { Median }=2.26 \\
\text { Range }=0.89-5.40\end{array}$} \\
\hline
\end{tabular}

"Head Start programs affiliated with community health centers.

${ }^{a}=$ Travel; ${ }^{b}=$ printing, clerical; ${ }^{c}=$ postage.

Direct annual personnel costs:

State 1: 1 hygienist @ $\$ 22,882$ /year ( $2 \%$ time), benefits included.

State 2: tnone reported; program is conducted by Head Start staff.

State 3: 2 hygienists @ \$17,264/year (50\%) time, no benefits.

State 4:2 hygienists @ $\$ 13.50$ /hour $\times 195.5$ hours, no benefits.

State 5: 1 full-time coordinator @ $\$ 36,000$ /year; 1 program director $@ \$ 47,000 /$ year (7\% time), fringe benefits included. 
TABLE 11

Direct Annual Costs of Fluoride Mouthrinse (0.2\% Weekly NaF) Programs in the US (in 1988 US\$)

\begin{tabular}{|c|c|c|c|c|c|c|c|c|}
\hline State & No.Schools & $\begin{array}{c}\text { No. } \\
\text { Children }\end{array}$ & $\begin{array}{l}\text { Age } \\
\text { or } \\
\text { Grade }\end{array}$ & $\begin{array}{l}\text { Personnel } \\
\text { Costs / } \\
\text { Year* }\end{array}$ & $\begin{array}{l}\text { Materials \& } \\
\text { Supplies/ } \\
\text { Year }\end{array}$ & $\begin{array}{l}\text { Other } \\
\text { Costs/ } \\
\text { Year }\end{array}$ & $\begin{array}{l}\text { Total } \\
\text { Costs/ } \\
\text { Year }\end{array}$ & $\begin{array}{c}\text { Costs/ } \\
\text { Child/ } \\
\text { Year }\end{array}$ \\
\hline 1 & 477 & 88,640 & Gr. K-6 & 17,461 & 28,365 & & 45,826 & 0.52 \\
\hline 2 & 300 & 130,000 & K-8 & 26,875 & 90,000 & & 116,875 & 0.90 \\
\hline 3 & 325 & 76,793 & $6-11$ yrs & 36,600 & 45,910 & & 82,510 & 1.07 \\
\hline 4 & 398 & 180,462 & Gr. K-8 & 50,136 & 164,220 & & 214,356 & 1.19 \\
\hline 5 & 263 & 124,659 & Gr. K-6 & 8,000 & 152,084 & & 160,084 & 1.28 \\
\hline 6 & 60 & 9,840 & $5-12$ yrs & 8,750 & 4,000 & & 12,750 & 1.30 \\
\hline 7 & 56 & 13,000 & K-6 & 6,999 & 8,500 & $1,500^{\mathrm{a}}$ & 16,999 & 1.31 \\
\hline 8 & 851 & 233,588 & Gr. $1-6$ & 69,500 & 245,700 & $46,800^{b}$ & 362,000 & 1.55 \\
\hline 9 & 136 & 36,155 & Gr. K-6 & 37,125 & 12,405 & $9,960^{c}$ & 59,490 & 1.65 \\
\hline 10 & 137 & 26,907 & 7-14 yrs & 15,400 & 29,060 & $1,200^{d}$ & 45,660 & 1.70 \\
\hline 11 & 1,537 & 358,263 & Gr. K-8 & 467,458 & 170,900 & & 638,358 & 1.78 \\
\hline All & & & & & & & \multicolumn{2}{|c|}{$\begin{array}{c}\text { Mean }=\$ 1.30 \\
\text { Median }=1.30 \\
\text { Range }=0.52-1.78\end{array}$} \\
\hline
\end{tabular}

* See Table 12.

${ }^{a}=$ printing costs; ${ }^{b}=\$ .20$ per child, heal th department administrative costs; ${ }^{c}=$ communications, travel, rent, and utilities; ${ }^{d}=$ travel.

TABLE 12

Direct Annual Personnel Costs for Fluoride Mouthrinse Programs in the US (in 1988 US\$)

\begin{tabular}{|c|c|c|c|c|c|c|c|c|c|c|c|}
\hline & State 1 & State 2 & State 3 & State 4 & State 5 & State 6 & State 7 & State 8 & State 9 & State 10 & State 11 \\
\hline \multicolumn{12}{|l|}{ Salaried } \\
\hline \# employed & 4 & 1 & 1 & 8 & 1 & 2 & None & 4 & 1 & $\mathrm{NA}^{*}$ & None \\
\hline Salaries & $\$ 49,250$ & $\$ 26,875$ & $\$ 32,000$ & $\$ 25,068$ & $\$ 24,024$ & $\$ 16,400$ & & $\$ 47,000$ & $\$ 31,778$ & & \\
\hline \multirow[t]{7}{*}{ (\% effort) } & 10 & 100 & 100 & 25 & 33.3 & 25 & & 33 & 25 & & \\
\hline & $\$ 18,927$ & & & & & $\$ 18,600$ & & $\$ 24,000$ & & & \\
\hline & 33 & & & & & 25 & & 100 & & & \\
\hline & $\$ 11,545$ & & & & & & & $\$ 20,000$ & & & \\
\hline & 20 & & & & & & & 75 & & & \\
\hline & $\$ 9,905$ & & & & & & & $\$ 20,000$ & & & \\
\hline & 20 & & & & & & & 75 & & & \\
\hline Subtotal & $\$ 15,461$ & $\$ 26,875$ & $\$ 32,000$ & $\$ 50,136$ & $\$ 8,000$ & $\$ 8,750$ & - & $\$ 69,500$ & $\$ 7,945$ & - & - \\
\hline \multicolumn{12}{|l|}{ Contract } \\
\hline \# employed & 3 & & 1 & & & & 5 & & 16 & & $25 t$ \\
\hline Wages & $\mathrm{NA}^{*}$ & & $\$ 15 / \mathrm{hr}$ & & & & $\$ 13.50 / \mathrm{hr}$ & & $\$ 14.59 / \mathrm{hr}$ & & $\begin{array}{c}\$ 8.90 \\
\$ 17.50 / \mathrm{hr}\end{array}$ \\
\hline \# hours & & & 306.7 & & & & 103.69 & & 125.0 & & \\
\hline Subtotal & $\$ 2,000$ & - & $\$ 4,600$ & - & - & - & $\$ 6,999$ & - & $\$ 29,180$ & - & - \\
\hline TOTAL & $\$ 17,461$ & $\$ 26,875$ & $\$ 36,600$ & $\$ 50,136$ & $\$ 8,000$ & $\$ 8,750$ & $\$ 6,999$ & $\$ 69,500$ & $\$ 37,125$ & $\$ 15,400$ & $\$ 467,458$ \\
\hline
\end{tabular}

Information not available.

tIncludes 1 coordinator, 5 field supervisors, 17 field consultants, 1 inventory specialist, and 1 secretary.

ing, and installation costs. The cost for engineering was estimated as 15 percent of the cost for new equipment; installation of equipment was calculated as twice the equipment costs, excluding the cost of containment for large systems (Reeves TG, Centers for Disease Control,
Atlanta; Magnant ML, Iowa Department of Health, Iowa City. Both personal communications, Feb 1989).

It should be noted that the total costs of fluoridation in a given community will vary greatly depending not only on the water plant's capacity and population served, but 
TABLE 13

Direct Costs of School Water Fluoridation Programs in the US, Based on Equipment Replacement Costs (in 1988 US\$)

\begin{tabular}{|c|c|c|c|c|c|c|c|c|c|c|c|}
\hline \multirow[b]{2}{*}{ State } & \multirow{2}{*}{$\begin{array}{c}\text { No. } \\
\text { Schools }\end{array}$} & \multirow{2}{*}{$\begin{array}{c}\text { No. } \\
\text { Students }\end{array}$} & \multirow{2}{*}{$\begin{array}{l}\text { Initial } \\
\text { Capital } \\
\text { Costs } \\
\left({ }^{\prime} 88 \$\right)^{*}\end{array}$} & \multicolumn{2}{|c|}{$\begin{array}{c}\text { Capital Costs/ } \\
\text { Yeart }\end{array}$} & \multirow{2}{*}{$\begin{array}{c}\text { Costs of } \\
\text { Chemical } \\
\text { /Year }\end{array}$} & \multirow{2}{*}{$\begin{array}{l}\text { Oper. } \\
\text { Costs / } \\
\text { Year** }\end{array}$} & \multirow{2}{*}{$\begin{array}{c}\text { Personnel } \\
\text { Costs/ } \\
\text { Year } \$\end{array}$} & \multirow{2}{*}{$\begin{array}{l}\text { Other } \\
\text { Costs }\end{array}$} & \multicolumn{2}{|c|}{$\begin{array}{c}\text { Cost/ } \\
\text { Student/Year }\end{array}$} \\
\hline & & & & $(2 \%)$ & $(4 \%)$ & & & & & $(2 \%)$ & $(4 \%)$ \\
\hline 1 & 4 & 2,500 & 8,100 & 630 & 729 & 300 & 400 & 200 & $500^{a}$ & 0.81 & 0.85 \\
\hline 2 & 103 & 28,896 & $154,500^{* * *}$ & 12,024 & 13,896 & 2,100 & 10,300 & 76,400 & & 3.49 & 3.55 \\
\hline 3 & 89 & 37,000 & 195,800 & 15,238 & 17,610 & 4,450 & 8,900 & 95,408 & $26,700^{b}$ & 4.07 & 4.14 \\
\hline $4 H$ & 134 & 48,500 & 241,200 & 18,772 & 21,694 & 16,000 & NA & 175,970 & $1,500^{c}$ & 4.38 & 4.44 \\
\hline 5 & $14 \neq t$ & 3,300 & 24,500 & 1,907 & 2,204 & 896 & 1,400 & 10,710 & $400^{d}$ & 4.64 & 4.73 \\
\hline $6+t$ & 28 & 4,880 & 63,280 & 4,925 & 5,691 & 2,500 & NA & 40,000 & & 9.72 & 9.88 \\
\hline All & & & & & & & & & $\begin{array}{r}\text { Mean } \\
\text { Medi } \\
\text { Range= }\end{array}$ & $\begin{array}{l}4.52 \\
=4.23 \\
1-9.72\end{array}$ & $\begin{array}{c}\$ 4.60 \\
4.29 \\
0.85-9.88\end{array}$ \\
\hline
\end{tabular}

"Includes equipment replacement cost, testing equipment, and installation.

tAnnualized capital cost at $2 \%$ and $4 \%$ over 15 years.

* Cost of lab testing and routine maintenance and repair.

†See Table 14.

${ }^{* *}$ No installation costs included; state employees install equipment.

ttSource: Dr. R. Gerlach (1989).

\#+Program discontinued Dec. 1988.

${ }^{a}=$ travel $\$ 350 /$ year, postage $\$ 150 /$ year; ${ }^{b}=$ travel, repair parts, $\$ 300 /$ school $/$ year; $^{c}=$ all other costs; ${ }^{d}=$ secretarial costs $\$ 400 /$ year.

TABLE 14

Direct Annual Personnel Costs for School Water Fluoridation Programs in the US (in 1988 US\$)

\begin{tabular}{|c|c|c|c|}
\hline State & Type of Personnel & $\begin{array}{c}\text { Cost } \\
(\$)\end{array}$ & $\begin{array}{c}\text { Total } \\
\text { Cost/Year }\end{array}$ \\
\hline State 1 & Honorarium for program supervisor & 200 & 200 \\
\hline State 2 & 1 technician @ $\$ 14,400 /$ year & 14,400 & 76,400 \\
\hline State 3 & 4 fluoride specialists and 1 support person $\$ 922 /$ school/year & 82,058 & \\
\hline \multirow{4}{*}{ State 4} & 6 technicians, appr. @ $\$ 22,048 /$ year (70\% time) & 92,603 & \\
\hline & 1 clerk $\$ 203.08 /$ year & 203 & \\
\hline & 1 lab employee @ $\$ 20,000 /$ year & 20,000 & \\
\hline & Administrative costs $\$ 58,664 /$ year & 58,664 & 175,970 \\
\hline State 5 & 1 fluoridation technician @ $\$ 765 /$ school/year & 10,710 & 10,710 \\
\hline State 6 & Administrative costs $\$ 3,500 /$ year & 3,500 & 40,000 \\
\hline
\end{tabular}

also on the type of installation, type of chemical, number of injection points, and natural level of fluoride. For example, communities \#12 and \#13 serve approximately the same size population, yet the system serving 2,800 residents costs almost twice as much in annual capital costs (Table 9). This can be explained not only in terms of the higher installation cost for its equipment, but also in that the system has six injection sites compared to only one for the smaller town. It is also worth noting that the cost of chemicals in these communities ranged from 16 cents/lb for bulk purchases of hydrofluosilicic acid to 98 cents/lb for sodium fluoride.

Fluoride Supplements. Seven out of 17 states surveyed had dietary fluoride supplement programs in ef- 
TABLE 15

Direct Annual Costs of Sealant Programs in the US (in 1988 US\$)

\begin{tabular}{|c|c|c|c|c|c|c|c|c|c|c|c|c|}
\hline \multirow[b]{2}{*}{ State } & \multirow{2}{*}{$\begin{array}{c}\text { No. } \\
\text { Students }\end{array}$} & \multirow{2}{*}{$\begin{array}{l}\text { Age } \\
\text { or } \\
\text { Grade } \\
\end{array}$} & \multirow{2}{*}{$\begin{array}{c}\text { Type } \\
\text { of } \\
\text { Sealant }\end{array}$} & \multirow{2}{*}{$\begin{array}{c}\text { Personnel } \\
\text { Costs/ } \\
\text { Year* }\end{array}$} & \multirow{2}{*}{$\begin{array}{l}\text { Materials } \\
\text { \& Supp- } \\
\text { lies/Year }\end{array}$} & \multicolumn{2}{|c|}{$\begin{array}{l}\text { Equipment } \\
\text { Costs/Yeart }\end{array}$} & \multirow{2}{*}{$\begin{array}{c}\text { Other } \\
\text { Costs/ } \\
\text { Year }\end{array}$} & \multicolumn{2}{|c|}{$\begin{array}{l}\text { Total Direct } \\
\text { Costs/Year }\end{array}$} & \multicolumn{2}{|c|}{$\begin{array}{l}\text { Cost/Student/ } \\
\text { Year (US\$) }\end{array}$} \\
\hline & & & & & & $(2 \%)$ & $(4 \%)$ & & $(2 \%)$ & $(4 \%)$ & $(2 \%)$ & $(4 \%)$ \\
\hline 1 & 1,450 & $7-12$ & $\begin{array}{l}\text { Light- } \\
\text { cured }\end{array}$ & 14,862 & 2,790 & 445 & 493 & $800^{a}$ & 18,897 & 18,945 & 13.03 & 13.07 \\
\hline 2 & 19,084 & Gr. $2,3,6,7$ & $\begin{array}{l}\text { Self- } \\
\text { cured }\end{array}$ & 210,100 & 31,400 & 11,873 & 12,684 & $19,800^{b}$ & 273,173 & 273,984 & 14.31 & 14.36 \\
\hline 3 & 1,603 & Gr. K-6 & $\begin{array}{l}\text { Light- } \\
\text { cured }\end{array}$ & 31,283 & 4,800 & $1,500^{c}$ & $1,500^{c}$ & $300^{d}$ & 37,883 & 37,883 & 23.63 & 23.63 \\
\hline $4 \mathrm{~A}$ & 3,801 & Gr. $2,3,6,7$ & $\begin{array}{l}\text { Self- } \\
\text { cured }\end{array}$ & 78,944 & $6,890^{* *}$ & 3,768 & 4,173 & $695^{e}$ & 90,297 & 90,702 & 23.76 & 23.86 \\
\hline $4 B$ & 3,392 & Gr. $2,3,6,7$ & $\begin{array}{l}\text { Self- } \\
\text { cured }\end{array}$ & 66,946 & 9,103 & 1,686 & 1,867 & $3,167^{f}$ & 80,902 & 81,083 & 23.85 & 23.90 \\
\hline 5 & 1,001 & Gr. 2,6 & $\begin{array}{l}\text { Light- } \\
\text { cured }\end{array}$ & 24,112 & 2,410 & 1,232 & 1,365 & $506^{8}$ & 28,260 & 28,393 & 28.23 & 28.37 \\
\hline All & & & & & & & & & & $\begin{array}{r}\text { Mean }= \\
\text { Mediar } \\
\text { Range }=1\end{array}$ & $\begin{array}{l}21.14 \\
=23.70 \\
03-28.23\end{array}$ & $\begin{array}{r}21.20 \\
23.75 \\
13.07- \\
28.37\end{array}$ \\
\hline
\end{tabular}

*See Table 16.

tCost of dental vans are annualized at $2 \%$ and $4 \%$ over 5 years; portable equipment annualized at same rate over 10 years.

**Includes $100 \mathrm{kits}$ of sealant materials donated by Johnson \& Johnson @ \$45.95 each.

$a=$ Maintenance and repair $\$ 200$, travel $\$ 600$.

$b=$ Travel $\$ 18,700$, maintenance/repair $\$ 1,100$.

$c=$ Leased dental van $\$ 1,500$.

d = Maintenance and repairs $\$ 200$, printing costs $\$ 100$.

$=$ Travel $\$ 495$, maintenance and repair $\$ 200$.

$=$ Maintenance and repair $\$ 200$, printing $\$ 1,180$, and travel $\$ 1,787$.

${ }^{8}=\$ 174 \mathrm{~m} /$ repair, $\$ 332$ promotional materials.

TABLE 16

Direct Annual Personnel Costs of Sealant Programs in the US, 1988 (in 1988 US\$)

\begin{tabular}{|c|c|c|c|}
\hline State & Type of Personnel & Cost & $\begin{array}{l}\text { Total } \\
\text { Cost/Year }\end{array}$ \\
\hline State 1 & Not available & $\$ 14,862$ & $\$ 14,862$ \\
\hline State 2 & $\begin{array}{l}63 \% \text { of personnel cost for entire program, includes: } 2 \text { dentists, } 6 \text { hygienists, and } \\
8 \text { assistants }\end{array}$ & 210,000 & 210,000 \\
\hline \multirow[t]{3}{*}{ State 3} & 2 hygienists, 792 hours @ $\$ 10 /$ hour & 15,840 & \\
\hline & 2 assistants, 720 hours $@ \$ 7 /$ hour & 10,080 & \\
\hline & 1 dentist, 298 hours $@ \$ 18 /$ hour & 5,364 & 31,284 \\
\hline \multirow[t]{3}{*}{ State 4A } & 1 coordinator, $60 \%$ time & NA & \\
\hline & 3 hygienists@ $\$ 10.85 /$ hour plus benefits & NA & \\
\hline & 3 assistants @ $\$ 7.01 /$ hour plus benefits & NA & 78,944 \\
\hline \multirow[t]{5}{*}{ State $4 \mathrm{~B}$} & 1 program coordinator, $30 \%$ time & 12,609 & \\
\hline & 2 hygienists, $10 \%$ time, 12 months/year & 30,402 & \\
\hline & 2 assistants, 28 hours / week, 9 months/year & 16,565 & \\
\hline & 1 secretary, $10 \%$ time, 12 months/year & 2,581 & \\
\hline & 1 dentist, $\$ 25 /$ hour plus travel & 4,789 & 66,946 \\
\hline \multirow[t]{4}{*}{ State 5} & 1 program coordinator, $50 \%$ time & 11,250 & \\
\hline & 2 hygienists, 298.35 hours @ $\$ 16 /$ hour & 9,547 & \\
\hline & 2 assistants, 185.4 hours $@ \$ 7 /$ hour & 2,595 & \\
\hline & 1 dentist, 45 hours $@ \$ 16 /$ hour & 720 & 24,112 \\
\hline
\end{tabular}


TABLE 17

Direct Costs of Applying APF Gel (1.23\%) Annually in the US (in 1988 US \$)

\begin{tabular}{|c|c|c|c|c|c|c|}
\hline Source* & \multicolumn{5}{|c|}{ Cost of Materials (US \$) } & Personnel: Average Cost/Hour \\
\hline Hoyt Labs Luride® & 16 & 10.36 & 0.12 & $0.28^{\mathrm{a}}$ & 0.40 & Dental assistant $\$ 6.99 /$ hour \\
\hline Premier Fluorident® & 16 & 16.50 & 0.18 & & & $\begin{array}{l}\text { Clinical services hygienist } \\
\$ 11.34 / \text { hour }\end{array}$ \\
\hline Oral B Checkmate & 16 & 20.95 & 0.23 & $0.43^{\mathrm{c}}$ & 0.66 & Dentist $\$ 29.41 /$ hour \\
\hline
\end{tabular}

"Prices quoted by manufacturers, shipping included.

tBased on 91 applications per 16-oz bottle (5 grams per application).

"Source: Survey of Dental Public Health Salaries, Jan 30, 1989. Dr. J. Alderman, Office of Dental Health, Georgia Department of Human Resources, Atlanta.

$a=$ Based on $\$ 14.00$ per box of 50 trays (dual or hinged gel trays).

$b=$ Based on $\$ 11.63$ per box of 30 trays (dual or hinged gel trays).

$c=$ Based on $\$ 21.34$ per box of 50 trays (dual or hinged gel trays).

TABLE 18

Annual Caries Increment of Children, Adults, and Elderly in the US, 1978-88, According to Age

\begin{tabular}{lccc}
\hline & \multicolumn{3}{c}{ Annual Caries Increments } \\
\cline { 2 - 4 } Age & Mean & Median & Range \\
\hline $5-17^{*}$ & 0.8 & 0.8 & $0.5-1.1$ \\
$5-17 \dagger$ & 1.4 & 1.2 & $0.8-2.6$ \\
$18-44$ & 1.1 & 1.1 & $0.7-1.6$ \\
$45-64$ & 1.5 & 1.5 & $1.2-1.9$ \\
$65+$ & 1.7 & 1.6 & $1.1-2.4$ \\
\hline
\end{tabular}

"Fluoridated communities.

tFluoride-deficient communities.

fect. Two were operated by Head Start programs and no cost data were available from them. Costs for the remaining five programs, and details of the number of employees, type of personnel, and their salaries or wage rates are presented in Table 10 . As with community water fluoridation programs, differences in costs are obvious among the various locations. Inspection of these data reveals that programs vary in terms of the number, type, and salary of personnel, as well as in their involvement of community volunteers, teachers, and other school personnel.

All programs reported using school volunteers or teachers to distribute fluoride tablets, although clearly they did not depend on such personnel equally. Personnel costs tended to fluctuate greatly from no reported cost (state \#2) up to 75 percent of total program costs (state \#5). None of the programs shown in Table 10 attributed as personnel costs the time required from teachers and volunteers, nor did any account for promotional costs.
TABLE 19

Direct Costs of Caries Prevention Programs in the US (in 1988 \$)

\begin{tabular}{lccc}
\hline & \multicolumn{3}{c}{ Annual Cost per Person } \\
\cline { 2 - 4 } Program & Mean & Median & Range \\
\hline Water fluoridation & 0.54 & 0.26 & $0.12-1.31$ \\
Fluoride supplements & 2.53 & 2.26 & $0.89-5.40$ \\
Fluoride mouthrinses & 1.30 & 1.30 & $0.52-1.78$ \\
School fluoridation & 4.56 & 4.26 & $0.81-9.88$ \\
Sealants & 21.17 & 23.73 & $13.03-28.37$ \\
& & & \\
\hline
\end{tabular}

Annual costs per student were calculated based on the number of children served by the programs. However, the reported number of students served by these fluoride supplement programs is an estimate of the actual number of participants. None of the states contacted measured participation rates, thus the annual cost per student is the cost of the supplement program for the "intended" population, rather than the number of students reached.

Fluoride Mouthrinses. Direct annual costs of fluoride mouthrinse programs in the US are shown in Tables 11-12. From a total of 17 states contacted, 13 operated such programs, and data were obtained from 11 of them. As with fluoride supplement programs, this type of preventive measure is conducted in schools and school personnel are frequently trained to carry out the weekly rinse activities. Not all programs, however, relied on school personnel to the same extent, nor did they hire similar numbers of people. For example, state \#5 calculated personnel costs based on one-third of the time of one program coordinator, who was paid $\$ 24,069$ annually. Thus, the total personnel cost reported represents 
approximately 5 percent of the total program costs. By contrast, the program in state \#11 functions with a number of field workers, consultants, clerical help, and a coordinator. For this program, a large part of the total direct cost (73\%) was due to personnel costs.

Cost of materials and supplies for the rinse programs can vary depending on how materials are dispensed. The least costly method is the use of pumps, which can be sterilized and reused several times, or the use of paper cups to distribute the rinsing solution to students. Premixed fluoride rinses are also available that do not require separate paper products for dispensing the solution, but are significantly higher in cost. The range in material costs per child can be demonstrated by examining data from programs in states \#2 and \#5. Although the target population for these programs is somewhat similar, state \#2 spent $69 \mathrm{cents} / \mathrm{child} /$ year in rinse products and paper supplies, while state \#5 spent $\$ 1.22 /$ child/year using pre-mixed rinses.

Only direct costs are summarized in Table 11, namely the cost of personnel, materials, supplies, and, in a few instances, administrative, travel, and printing costs. No costs were included for teachers' and volunteers' time. As noted in the discussion of fluoride supplement programs, the annual cost of fluoride mouthrinse programs per student is based on the intended population, rather than the actual number of students participating in the program. These costs ranged from 52 cents to $\$ 1.78$ per child per year.

School Water Fluoridation. Relatively few states operate programs of school fluoridation, so data received were naturally limited. From a total of 17 states surveyed, cost data were obtained from three programs currently in operation, and from another program where school fluoridation had been discontinued in 1988. Information for the fifth and sixth programs, one of which is also no longer in operation, were obtained from a recent survey of school water fluoridation in the US (Gerlach R, Division of Dental Health, Vermont Department of Health. Personal communication, Mar 1989). Although a number of other states, notably in the Southwest and Alaska, have programs in effect, most are small installations not likely to be representative of other regions of the country.

Capital costs for all programs listed in Table 13 were based on the replacement cost for existing fluoridation and testing equipment. Installation costs were also included as initial capital expenditures, except for one location (state \#2) where state employees install their own fluoridators. The cost per system and cost per installation did not vary greatly among the six programs, ranging from $\$ 1,500$ to $\$ 2,200$ per unit/school (fluoridator, testing equipment, pump, plumbing), and from $\$ 300$ to $\$ 500$ per installation per school. In contrast, the cost of chemicals ranged from $\$ 20.30$ per school per year to $\$ 119$ per school/year. The greatest difference in program costs can be noted in the number and cost of personnel utilized by the programs, summarized in Table 14.

Sealants. Tables 15-16 show the data obtained for a number of sealant programs in operation in the US. Cost information was available from five states; the remaining 11 states surveyed either offered sealants as part of a clinical program, did not have cost data, or had no program. Only two of the six programs listed in Table $15 \mathrm{had}$ initiated sealant activities during 1988 (states \#1, \#3), all others were ongoing projects implemented during earlier years. Thus, initial equipment costs for programs in states \#2, 4A, 4B, and 5 needed to be expressed in 1988 dollars by either adjusting for inflation, or by using new equipment costs. Because the type of equipment being used in these four programs was known, and similar if not identical models are still available from the manufacturers, replacement costs were used. Once annualized, equipment costs were added to personnel, materials, supplies, and other costs to derive the cost per student per year.

One could argue that the cost of a sealant program is not only the cost of placing sealants, but also the cost of examining all students and subsequently treating those eligible for the service. Thus a distinction should be made between the annual cost per student sealed and the cost per student examined. The annual cost, which ranged from $\$ 13.08$ to $\$ 28.43$ per child/year, represents (with two exceptions, states \#4A and 4B) the cost per student sealed, not per student examined. The real cost of a program is therefore likely to be higher when the cost of screening is included.

Self- and Professionally Applied Gels. Data could not be located, either in the literature or from program directors for the sixth type of program-that is, self- and professionally applied fluorides. Therefore, the cost of the basic materials of 1.23 percent APF gel and the cost of fluoride gel trays were included in Table 17. Although state practice acts will differ in the type of personnel and supervision required for such programs, minimally one would need the services of hygienists and assistants, and in some instances supervisory dentists. The wage rates of these dental health professionals were included to assist work groups to calculate direct program costs.

Summary of Findings. Caries incidence for age groups 5-17, 18-44, 45-64, and 65+ are summarized in Table 18. The data are presented as mean, median, and range of increment/year for use in the workshop. Some of the studies included in this review reported findings as DMFS per year; others used DFS per year or DFS per 100 surfaces at risk. For this reason, the reader is referred to Tables 1-7 for more details. The direct costs of the various caries prevention programs obtained for the workshop are summarized in Table 19. All cost data are presented as reported from dental public health personnel, water plant operators, and fluoridation engineers. 


\section{References}

1. Bell RM, Klein SP, Bohannan HM, Disney JA, Graves RC, Madison R. Treatment effects in the National Preventive Dentistry Demonstration Program. R-3072-RWJ. Santa Monica, CA: Rand Corporation, 1983.

2. Ripa LW, Leske GS, Sposato A, Varma A. Effect of prior toothcleaning on biannual professional acidulated phosphate fluoride topical fluoride gel-tray treatments. Caries Res 1984 Sept-Oct;18:457-64.

3. Abrams RG, Chambers DW. Caries-inhibiting effect of a stannous fluoride silica gel dentifrice: a three-year clinical study. Clin Prev Dent 1980 Jan-Feb;2:22-4, 26-7.

4. Triol CW, Kranz SM, Volpe AR, Frankl SN, Alman JE, Allard RL. Anticaries effect of a sodium fluoride rinse and an MFP dentifrice in a nonfluoridated water area: a thirty-month study. Clin Prev Dent 1980 Mar-Apr;2:13-5.

5. Glass RL. Caries reduction by a dentifrice containing sodium monofluorophosphate in a calcium carbonate base. Clin Prev Dent 1981 Jul-Aug;3:6-8.

6. Clark DC, Stamm JW, Tessier C, Robert G. The final results of the Sherbrooke-Lac Megantic fluoride varnish study. Can Dent Assoc J 1987 Dec;53:919-22.

7. Ringelberg ML, Conti AJ, Ward CB, Clark B, Lotzkar S. Effectiveness of different concentrations and frequencies of sodium fluoride mouthrinse. Pediatr Dent 1982 Dec;4:305-8.

8. Heifetz SB, Meyers RJ, Kingman A. A comparison of the anticaries effectiveness of daily and weekly rinsing with sodium fluoride: final results after three years. Pediatr Dent 1982 Dec;4:300-3.

9. Ripa LW, Leske GS, Forte F, Varma A. Caries inhibition of mixed $\mathrm{NaF}-\mathrm{Na}_{2} \mathrm{PO}_{3} \mathrm{~F}$ dentifrices containing $1,000 \mathrm{ppm}$ and $2,500 \mathrm{ppm} \mathrm{F}$ : 3-year results. J Am Dent Assoc 1988 Jan;116:69-73.

10. Burt BA, Eklund SA, Morgan KJ, Larkin FE, Guire KE, Brown LO, Weintraub JA. The effects of sugars intake and frequency of ingestion on dental caries increment in a three-year longitudinal study. J Dent Res 1988 Nov;67:1422-9.

11. Glass RL. A two-year clinical trial of sorbitol chewing gum. Caries Res 1983 Jul-Aug;17:365-8.

12. Lu KH, Ruhlman CD, Chung KL, Sturzenberger OP, Lehnhoff RW. A three-year clinical comparison of a sodium monofluorophosphate dentifrice with sodium fluoride dentifrices on dental caries in children. J Dent Child 1987 Jul-Aug;54:241-4.

13. Conti A], Lotzkar S, Daley R, Cancro L, Marks RG, McNeal DR. A 3-year clinical trial to compare efficacy of dentifrices containing $1.14 \%$ and $0.76 \%$ sodium monofluorophosphate. Community Dent Oral Epidemiol 1988 Jun;16:135-8.

14. Bagramian RA. A 5-year school-based comprehensive program in Michigan, USA. Community Dent Oral Epidemiol 1982 Aug:10:2347.

15. Driscoll WS, Swango PA, Horowitz AM, Kingman A. Carlespreventive effects of daily and weekly fluoride mouthrinsing in a fluoridated community: final results after 30 months. J Am Dent Assoc 1982 Dec;105:1010-3.

16. Glass RL, Peterson JK, Bixler D. The effects of changing caries prevalence and diagnostic criteria on clinical trials. Caries Res 1983 Mar-Apr;17:145-51.

17. Fogels HR, Meade JJ, Griffith J, Miragliuolo R, Cancro LP. A clinical investigation of a high-level fluoride dentifrice. J Dent Child 1988 May-Jun;55:210-5.

18. Glass RL, Alman JE, Chauncey HH. A 10-year longitudinal study of caries incidence rates in a sample of male adults in the USA. Caries Res 1987 Jul-Aug;21:360-7.

19. Hyman JJ. Dental caries in the active duty navy population. Naval Dental Research Institute Progress Report, NDRI-PR 83-14, 1983.

20. Ripa LW, Leske GS. Clinical trial of the efficacy of sodium fluoride mouthrinsing in preventing dental caries in adults. Final report to NIDR. Contract no NO1-DE-324000, Jul 1987.

21. US Public Health Service, National Institutes of Health. NIDR. Oral health of United States adults. The national survey of oral health in the US employed adults and seniors: 1985-1986. NIH pub no 872868. Washington, DC: Government Printing Office, 1987.

22. Hand JS, Hunt RJ, Beck JD. Coronal and root caries in older Iowans: 36-month incidence. Gerodontics 1988 Jun;4:136-9.

23. Banting DW, Ellen RP, Fillery ED. A longitudinal study of root caries: baseline and incidence data. J Dent Res 1985 Sept;64:1141-4.

24. Hand JS, Hunt RJ, Beck JD. Incidence of coronal and root caries in an older adult population. J Public Health Dent 1988 Winter;48:149.

25. US Department of Labor. Bureau of Labor Statistics. Current labor statistics: price data. Monthly Labor Rev 1989 Jan;112:105. 